\title{
WHEN RURAL ENTREPRENEURIAL MARKETING DOES NOT WORK: THE CASE OF OTOP FAILURE IN THAILAND
}

\author{
Edward Kasabov, University of Exeter, United Kingdom \\ Pitchaya Panupattanapong, University of Bath, United Kingdom
}

\begin{abstract}
Marketing scholarship continues to theorise about the significance of marketing resources to firm-level success, and resources are commonly viewed as the source of competitive advantage (Day \& Wensley, 1988; Aaker, 1989; Webster, 1992; O'Donnell et al., 2002; Morgan el at., 2009). Businesses which effectively and efficiently deploy and exploit their market-based assets are assumed to be better placed at attaining superior business performance (Morgan \& Vorhies, 2005). However, the input of firm resources to competitive advantage has generally been theorised and empirically examined in the context of large companies. Less frequent are discussions about resources in small firms and entrepreneurial ventures (O'Donnell et al., 2002). These issues deserve empirical testing, though, since entrepreneurship plays a substantial role in economic development and contributes to rural communities (Beaulieu, 2002; Emery et al., 2003; Levitte, 2004; Grey \& Collins-Williams, 2006; Steinberg et al., 2010). In Thailand, promoting rural entrepreneurship has been one of the government's main aims during the past decade, with the number of Thai entrepreneurs and rural enterprises increasing steadily (Tongboonrawd \& Sukpradit, 2007). This paper empirically evaluates one programme aimed at encouraging rural entrepreneurship in Thailand, One Tambon One Product (OTOP), by interviewing key stakeholders in three rural communities located close to Bangkok which have been involved in the OTOP programme for the past four years. Interviews with OTOP programme managers, entrepreneurs, and employees reveal sources and consequences of the successful and unsuccessful deployment of marketing resources by entrepreneurs who participate in the OTOP programme. Factors affecting entrepreneurship difficulties and failure have been identified, including problems in attracting human resources and capital. Less frequently reported findings about entrepreneurs' attitudes and behaviour are also explored. The investigation of the nature and sources of failure and the proposed framework of rural entrepreneurial failure seek to contribute to a fuller understanding of entrepreneurial marketing theory.
\end{abstract}

